\title{
PENGARUH PENGUNGKAPAN CORPORATE SOCIAL RESPONSIBILITY (CSR) TERHADAP KINERJA KEUANGAN DI PERUSAHAAN YANG GO PUBLIC
}

\author{
Muhammad Pondrinal \\ Universitas Putra Indonesia YPTK Padang, Indonesia \\ Email : m.pondrinal@gmail.com
}

\begin{abstract}
ABSTRAK
Penelitian ini bertujuan untuk menguji pengaruh Corporate Social Responsibility (CSR) terhadap kinerja keuangan perusahaan (Return On Asset). Dalam penelitian ini kinerja keuangan diukur dengan menggunakan ROA. Variabel independen yang digunakan dalam penelitian ini adalah Corporate Social Responsibility dengan 79 pengungkapan menurut GRI, sedangkan variabel dependennya adalah Kinerja Keuangan. Sampel penelitiannya adalah perusahaan pertambangan yang terdaftar di bursa efek indonesia dengan periode penelitian 2010-2014. Adapun sampel yang digunakan adalah 4 perusahaan.Hasil penelitian menunjukkan Pengungkapan Corporate Social Responsibility (CSR) berpengaruh positif terhadap Kinerja keuangan. Besarnya pengaruh yang diberikan oleh variabel Coporate Social Responsibility (CSR) adalah sebesar 38,2\%, sedangkan sisanya sebesar $61.8 \%$ dipengaruhi oleh faktor lain yang tidak diteliti dalam penelitian ini.
\end{abstract}

Primay Key : Corporate Social Responsibility, Return on Assets (ROA).

\section{Pendahuluan}

Dalam dunia bisnis, perusahaan atau lembaga yang sudah mendeklarasikan perusahaan yang go public dituntut untuk selalu berkembang dan menyesuaikan diri dengan perkembangan yang terjadi di lingkungan eksternal. Kunci utama pencapaian keberlangsungan adalah adanya penerimaan publik akan kehadiran perusahaan. Keberlangsungan dapat dicapai dengan lahirnya suatu konsep yang dikenal sebagai Corporate Social Responsibility yang selanjutnya disingkat menjadi CSR. Corporate Social Responsibility merupakan sebuah konsep terintegrasi yang menggabungkan aspek bisnis dan sosial dengan selaras yang bertujuan agar perusahaan dapat membantu tercapainya kesejahteraan para stakeholders dan perusahaan dapat mencapai laba secara maksimum.

Masalah lingkungan yang diakibatkan oleh aktivitas perusahaan telah banyak ditemukan seperti banjir, longsor, pencemaran air sungai, polusi udara, dan lainnya. Sebagai contohnya adalah pencemaran lingkungan di Teluk Buyat karena aktivitas pertambangan oleh PT Newmont Minahasa Raya (PT NMR). Teluk Buyat dijadikan sebagai lokasi pembuangan limbah tailing tambang PT NMR yang mengakibatkan ekosistem perairan laut di Teluk Buyat rusak parah akibat buangan tailing setiap harinya. Penerapan Corporate Social Responsibility menjadi bentuk tanggung jawab perusahaan terhadap kerusakan lingkungan yang terjadi dan merupakan bentuk kepedulian perusahaan dalam menjaga lingkungan sekitar sehingga perusahaan tidak hanya mengeksploitasi alam secara habis-habisan namun juga melakukan reklamasi.

Juga kasus yang terjadi di Provinsi Riau, masyarakat Duri yang hidup di daerah dekat wilayah operasi PT. Caltex Pacific Indonesia (CPI) mengalami kerugian dalam aspek kesehatan dan ekonomis. Ekspansi daerah operasi perusahaan ini membuat jarak daerah pengeboran minyak dengan pemukiman penduduk hanya sekitar 200 meter. Dalam kondisi seperti ini pengeboran minyak menyebabkan sumur-sumur 
penduduk menjadi kering. Akibatnya konsumsi air bersih menjadi masalah serius. Air bersih menjadi barang yang langka. Untuk memperolehnya masyarakat harus membelinya. Selain sumur menjadi kering, hal yang sama juga terjadi pada kolam ikan yang dikelola penduduk. Usaha rumah tangga ini menjadi tidak bisa dilanjutkan oleh masyarakat.

Penerapan Corporate Social Responsibility memang membutuhkan biaya yang cukup besar, namun dengan adanya Corporate Social Responsibility, perusahaan akan mendapatkan keuntungan yang jauh lebih besar yakni investasi jangka panjang yang di mana akan berdampak pada keberlangsungan perusahaan dikarenakan sekarang perusahaan telah dihadapkan pada tanggung jawab yang berpijak pada triple bottom line yakni dilihat dari aspek sosial, lingkungan, dan keuangan. Hal ini didukung dengan adanyaUU Perseroan Terbatas No.40/2007 pasal 74 bahwa setiap perusahaan (penanaman modal) berkewajiban untuk melaksanakan tanggung jawab sosial perusahaan, danPeraturan Pemerintah Nomor 47 Tahun 2012 tentang tanggung jawab sosial dan lingkungan Perseroan Terbatas yang diterbitkan pada bulan April 2012.

Akan tetapi tidak semua perusahaan mengungkapkan tentang aktivitas sosialnya di dalam laporan tahunan. Hal ini dikarenakan jenis pengungkapannya masih bersifat sukarela (voluntary disclosure). Sebagaimana tertulis dalam Pernyataan Standar Akuntansi Keuangan (PSAK) No 1 (revisi per 1 Juli 2009) paragraf kesembilan "Perusahaan dapat pula menyajikan laporan tambahan seperti laporan mengenai lingkungan hidup dan laporan nilai tambah (value added statement) khususnya bagi industri dimana faktor-faktor lingkungan hidup memegang peranan penting dan bagi industri yang menganggap pegawai sebagai kelompok pengguna laporan keuangan yang memegang peranan penting".

Standar akuntansi keuangan di Indonesia belum mewajibkan perusahaan untuk mengungkapkan informasi sosial terutama informasi tanggung jawab sosial perusahaan terhadap lingkungan. Perusahaan akan mempertimbangkan biaya dan manfaat yang akan diperoleh ketika mereka memutuskan untuk mengungkapkan informasi ini. Bila manfaat yang akan diperoleh dengan pengungkapan informasi lebih besar dibandingkan dengan biaya yang dikeluarkan untuk mengungkapkannya, maka perusahaan akan sukarela mengungkapkan informasi tersebut. Walaupun sifatnya sukarela, lingkungan eksternal pada saat sekarang ini sangat bergejolak. Pembahasan-pembahasan yang terjadi sangat dinamis dan terkadang pengaruhnya terhadap manajemen tidak dapat diperkirakan terlebih dahulu. Dengan demikian sudah semestinya setiap perusahaan perlu menyadari akan tanggung jawab sosial perusahaan (corporate social responsibility).

Salah satu jenis perusahaan yang menarik untuk dicermati dalam penerapan Corporate Social Responsibility yaitu perusahaan pertambangan. Sebagai perusahaan pertambangan, mereka menyadari bahwa kegiatan operasi perusahaan memiliki dampak secara langsung terhadap lingkungan dan masyarakat sekitar. Fenomena yang terjadi pada perusahaan pertambangan adalah pada setiap kegiatan penambangan berpotensi memberikan dampak negatif terhadap lingkungan sekitar lokasi kegiatan penambangan.

Pengungkapan Corporate Social Responsibility dapat dijadikan sebagai salah satu faktor dalam pengukuran kinerja perusahaan. Selain itu, ukuran perusahaan juga diindikasi dapat berpengaruh terhadap kinerja keuangan suatu perusahaan. Ukuran perusahaan diduga dapat mempengaruhi aktivitas operasional perusahaan sehingga akan berdampak pada kinerja keuangan perusahaan. Dengan melihat kinerja perusahaan dapat terlihat bagaimana kondisi perusahaan pada periode waktu tertentu yang akan berguna dalam pengambilan keputusan.

Kinerja perusahaan yang sering menjadi sorotan adalah kinerja keuangannya karena merupakan salah satu faktor yang menjadi acuan investordalam membeli saham. Rasio profitabilitas digunakan sebagai dasar 
untuk mengukur kinerja keuangan perusahaan dikarenakan tujuan utama suatu perusahaan didirikan adalah untuk memperoleh laba, sehingga dengan menggunakan metode ini kita dapat mengetahui kemampuan perusahaan dalam menghasilkan laba. Indikator daya tarik bisnis dapat diukur dari profitabilitas usaha, yaitu melalui Return on Assets (ROA) dan Return On Equity (ROE).

Berdasarkan uraian yang telah dikemukakan, maka penulis tertarik untuk melakukan penelitian dengan judul : "Pengaruh Pengungkapan Corporate Social Responsibility Terhadap Kinerja Keuangan di Perusahaan yang Go Public (Study Kasus Pada Perusahaan Pertambangan yang Terdaftar di Bursa Efek Indonesia 2010-2014)".

\section{Tinjauan pustaka}

\subsection{Teori Stakeholder (Stakeholder Theory)}

Menurut Azheri (2012:119) Stakeholders theory adalah suatu pendekatan yang didasarkan atas bagaimana mengamati, mengidentifikasi dan menjelaskan secara analitis tentang berbagai unsur yang dijadikan dasar dalam mengambil suatu keputusan dan tindakan dalam menjalankan aktivitas usaha. Ghozali dan Chariri, dalam Kusumadilaga (2010:11) Teori stakeholder mengatakan bahwa perusahaan bukanlah entitas yang hanya beroperasi untuk kepentingan sendiri namun harus memberikan manfaat bagi stakeholdernya. Dengan demikian, keberadaan suatu perusahaan sangat dipengaruhi oleh dukungan yang diberikan oleh stakeholder kepada perusahaan tersebut.

Azheri (2012:112) mengungkapkan bahwa stakeholders theory lahir atas kritikan dan kegagalan shareholders theory atau Friedman's Paradigm dalam upaya meningkatkan tanggung jawab perusahaan, yang terletak pada tanggung jawab tunggal manajemen kepada shareholders. Kegagalan tersebut mendorong munculnya stakeholders theory yang melihat shareholders sebagai bagian dari stakeholders itu sendiri.

\subsection{Teori Legimitasi (Legitimacy Theory)}

O'Donovan dalam Utari (2014:10) berpendapat legitimasi organisasi dapat dilihat sebagai sesuatu yang diberikan masyarakat kepada perusahaan dan sesuatu yang diinginkan atau dicari perusahaan dari masyarakat. Dengan demikian, legitimasi merupakan manfaat atau sumber daya potensial bagi perusahaan untuk mempertahankan hidup (going concern).Teori legitimasi menjelaskan bahwa praktik pengungkapan tanggung jawab sosial perusahaan harus dilaksanakan sebaik mungkin agar nantinya aktivitas dan kinerja perusahaan mendapat respon yang baik masyarakat. Adapun dengan respon positif tersebut akan dapat melahirkan nilai yang baik perusahaan dimata masyarakat dan otomatis dapat meningkatkan pencapaian laba oleh pihak perusahaan. Tentu hal ini akan menjadi keuntungan bagi perusahaan, karena dengan nilai yang sudah terbangun, akan bisa memberikan ketertarikan pada pihak investor untuk mau berinvestasi di perusahaan.

Dowling dan Pfeffer dalam Husnan (2013:10) mengatakan: "Legitimasi merupakan hal yang penting bagi organisasi, batasan-batasan yang ditekankan oleh norma-norma dan nilai-nilai sosial, reaksi terhadap batasan tersebut mendorong pentingnya analisis perilaku organisasi dengan memperhatikan lingkungan".

\subsection{Signaling Theory}

Teori sinyal menjelaskan mengapa perusahaan mempunyai dorongan untukmemberikan informasi laporan keuangan pada pihak eksternal. Dorongan perusahaan untuk memberikan informasi karena terdapat asimetri informasi antara perusahaan dan pihak luar karena perusahaan mengetahui lebih banyak mengenai perusahaan dan prospek yang akan datang daripada pihak luar (investor, kreditor). Kurangnya informasi bagi pihak luar mengenai perusahaan menyebabkan mereka melindingi diri mereka dengan 
memberikan harga yang rendah untuk perusahaan. Perusahaan dapat meningkatkan nilai perusahaan dengan mengurangi informasi asimetri. Salah satu cara untuk mengurangi informasi asimetri adalah dengan memberikan sinyal pada pihak luar, salah satunya berupa informasi keuangan yang dapat dipercaya dan akan mengurangi ketidakpastian mengenai prospek perusahaan yang akan datang (Wolk dkk, dalam Rahayu 2010:9).

\subsection{Corporate Social Responsibility (CSR)}

Menurut The World Council for Sustainability Development (WBCSD) lembaga internasional yang berdiri tahun 1995 merumuskan CSR sebagai "the continuing commitnment by business to behave ethically and contribute to economic development while improving the quality of life of the workforce and their families as well as of the local community and society at large to improve their quality of life". Corporate Social Responsibility atau tanggung jawab sosial perusahaan didefenisikan sebagai suatu komitmen berkelanjutan oleh dunia usaha untuk memberikan kotribusi kepada pembangunan ekonomi dari komunitas setempat ataupun masyarakat secara luas, bersamaan dengan peningkatan taraf hidup pekerjanya beserta seluruh keluarganya.

Azheri (2012:28) merumuskan pengertian CSR sebagai komitmen perusahaan untuk melaksanakan kewajiban yang didasarkan atas keputusan untuk mengambil kebijakan dan tindakan dengan memerhatikan kepentingan para stakeholder dan lingkungan dimana perusahaan melakukan aktivitasnya yang berlandaskan pada ketentuan hukum yang berlaku.

\subsection{Kinerja Keuangan}

Menurut Fahmi (2011:239) kinerja keuangan adalah suatu analisis yang dilakukan untuk melihat sejauh mana suatu perusahaan telah melaksanakan dengan menggunakan aturan-aturan pelaksanaan keuangan secara baik dan benar. Seperti dengan membuat suatu laporan keuangan yang telah memenuhi standard dan ketentuan dalam SAK atau GAAP dan lainnya.

Berdasarkan telaah pustaka yang telah dilakukan diatas, maka model pemikiran teoritis yang dikembangkan pada penelitian ini terlihat pada gambar berikut ini :

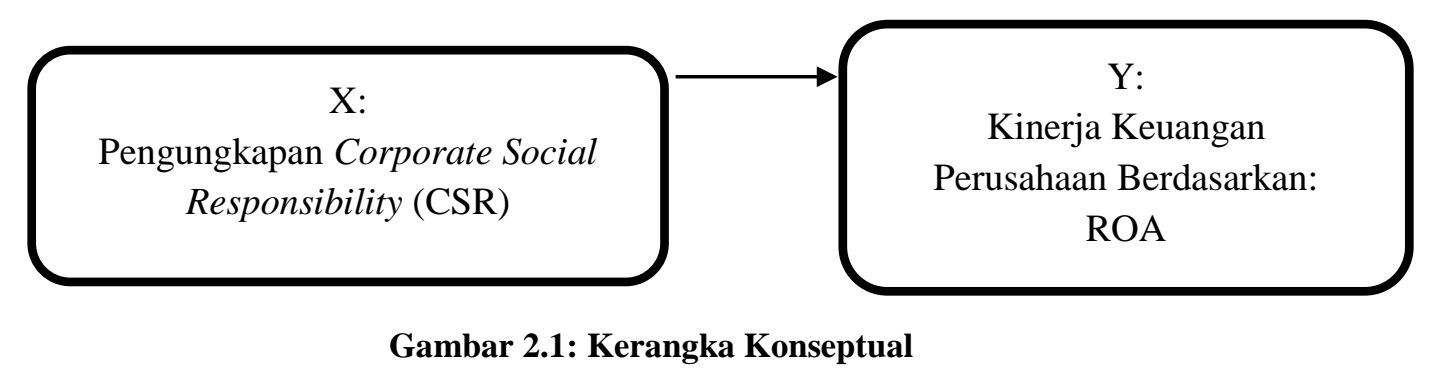

\section{METODOLOGI PENELITIAN}

Jenis penelitian ini adalah penelitian asosiatif untuk hubungan kausal yang ditujukan untuk menjelaskan pengaruh antara satu variabel dengan variabel yang lainnya, dalam hal ini yang menjadi variabel independentnya adalah Corporate Social Responsibility. Sedangkan yang menjadi variabel dependentnya adalah kinerja keuangan. Dalam penelitian ini, data yang dikumpulkan berupa data kuantitatif, yaitu data yang diukur dengan skala numerik. Sumber data penelitian ini adalah data sekunder, berupa laporan berkelanjutan atau sustainability report. 
Teknik pengumpulan data dalam penelitian ini adalah metode dokumentasi yaitu penggunaan data yang berasal dari dokumen-dokumen yang sudah ada. Pengumpulan data dilakukan dengan melihat data-data yang diperlukan, mencatat, dan menganalisis sustainability report perusahaan pertambangan tahun 2010-2014.

\section{HASIL DAN PEMBAHASAN}

Teknik analisis data dalam penelitian ini menggunakan regresi linear sederhana, yaitu suatu pendekatan yang bertujuan untuk melihat sejauh mana kemampuan dari variabel bebas atau independen (Corporate Social Responsibility) dalam menjelaskan atau mempengaruh variabel terikat atau dependen yang dalam hal ini adalah variabel kinerja keuangan (ROA). Namun sebelum dilakukan analisis regresi linear sederhana, telah dilakukan pengujian persyaratan atau asumsi klasik yang meliputi uji normalitas .Dimana secara keseluruhan temuan menunjukan model yang dibangun dapat memenuhi model yang layak atau dapat menjelaskan kerangka konseptual yang telah dibentuk dalam menjelaskan hipotesis penelitian.

Berikut ringkasan hasil pengujian regresi linear sederhana, sebagaimana yang tanpa pada tabel di bawah ini :

Tabel 4.1 Hasil Nilai Koefisien Regresi

\begin{tabular}{|c|c|c|c|c|c|}
\hline \multicolumn{6}{|c|}{ Coefficients $^{a}$} \\
\hline \multirow[t]{2}{*}{ Model } & \multicolumn{2}{|c|}{ Unstandardized Coefficients } & Standardized Coefficients & \multirow[t]{2}{*}{$\mathrm{T}$} & \multirow[t]{2}{*}{ Sig. } \\
\hline & B & Std. Error & Beta & & \\
\hline (Constant) & 1.085 & 4.003 & & .271 & .790 \\
\hline CSR & 16.780 & 4.703 & .644 & 3.568 & .002 \\
\hline
\end{tabular}

a. Dependent Variable: Kinerja Keuangan

Sumber: Hasil Pengolahan data SPSS 21

Berdasarkan ringkasan hasil regresi linear di atas, secara keseluruhan variabel independen (Corporate Social Responsibility) dapat mempengaruhi variabel kinerja keuangan sebagai variabel dependen. Ini dapat dilihat dari nilai signifikan variabel independen yang nilainya jauh dibawah kesalahan menolak data atau $\alpha=5 \%$.

Dengan demikian, dapat dibentuk persamaan regresi linear sederhana sebagai berikut:

$\mathrm{Y}=1.085+16.780(\mathrm{CSR})+\mathrm{e}$

\subsection{Pengungkapan Corporate Social Responsibility Perusahaan Pertambangan yang Terdaftar di Bursa Efek Indonesia 2010-2014.}

Secara umum komposisi Corporate Social Responsibility (CSR) dari perusahaan yang menjadi sampel dengan indikator jumlah item yang diungkapkan perusahaan dibagi dengan jumlah item yang diharapkan diungkapkan. Berdasarkan tabel nilai terendah pengungkapan CSR sebesar 0,20 atau $20 \%$ pada PT. Tambang Batubara Bukit Asam (Persero) Tbk dan PT. Petrosea Tbk ditahun 2014, dikarenakan pengimplementasian pengungkapkan CSR hanya 16 item dari yang seharusnya 79 item, nilai tersebut sangat rendah diakibatkan karenahasil CSR dibawah rata-rata dari sampel penelitian pada perusahaan pertambangan yang terdaftardi BEI tahun 2010-2014. Dan untuk CSR dengan nilai tertinggi sebesar 1,00 atau $100 \%$ pada semua perusahaan sampel ditahun 2010-2012, yang mengimplementasikan 
pengungkapan CSR 79 itemdari yang seharusnya 79 item, nilai tersebut sangat tinggi diakibatkan karena hasil CSR diatasrata-rata dari sampel penelitian pada perusahaan pertambangan yang terdaftar di BEI tahun 2010-2014.

Nilai rata-rata pengungkapan pengungkapan CSR sebesar 0,80 atau $80 \%$ artinya tingkat pengungkapan Corporate Social Responsibility pada perusahaan bersifat lengkap, mengacu pada sub bab 3.5.1, untuk menentukan kriterianya sebagai berikut :

$$
\begin{aligned}
& \text { Panjang Kelas }=\frac{(\text { Nilai Maksimal }- \text { Nilai Minimal })}{5} \\
& \text { Panjang Kelas }=\frac{(1,00-0,20)}{5}=0.16
\end{aligned}
$$

Tabel 5.1 Kriteria Pengungkapan Corporate Social Responsibility

\begin{tabular}{|c|c|}
\hline Interval & Kriteria \\
\hline $0,20-0,36$ & Tidak Lengkap \\
\hline $0,37-0,53$ & Kurang Lengkap \\
\hline $0,54-0,70$ & Cukup Lengkap \\
\hline $\mathbf{0 , 7 1}-\mathbf{0 , 8 7}$ & Lengkap \\
\hline $0,88-1,00$ & Sangat Lengkap \\
\hline
\end{tabular}

Sumber : Data sekunder yang diolah, 2015

\subsection{Kinerja Keuangan Perusahaan Pertambangan Berdasarkan Return On Asset (ROA) Perusahaan Pertambangan yang Terdaftar di Bursa Efek Indonesia 2010-2014}

Berdasarkan tabel berkaitan dengan variabel Kinerja Keuangan dengan indikator rasio Return On Asset(ROA) dengan demikian untuk nilai terendah rasio Return On Asset (ROA) 0,5\% pada PT. Petrosea Tbk tahun 2014. Nilai tersebut sangat rendah dan jauh dibawah rata-ratadikarenakan laba yang kecil sementara memiliki nilai asset yang cukup besar.dan untuk rasio Return On Asset (ROA) dengan nilai tertinggi mencapai 26,8\% pada PT. Tambang Batubara Bukit Asam (Persero) Tbk. Nilai tersebut sangat tinggi diakibatkan karena hasil rata-rata rasio Return On Asset (ROA) atau pengembalian keuntungan sesuai dengan yang diharapkan atau diatas rata-rata dari perusahaan pertambangan yang terdaftar di Bursa Efek Indonesia tahun 2010-2014.

Nilai rata-rata atau mean rasio Return On Asset (ROA) dari perusahaan yang menjadi sampel adalah sebesar $14,45 \%$, artinya tingkat kinerja keuangan pada perusahaan bersifat Sedang, mengacu pada sub bab 3.5.1, untuk menentukan kriterianya sebagai berikut :

$$
\begin{aligned}
& \text { Panjang Kelas }=\frac{(\text { Nilai Maksimal }- \text { Nilai Minimal })}{5} \\
& \text { Panjang Kelas }=\frac{(26,8-0,50)}{5}=5,25
\end{aligned}
$$

Tabel 5.2 Kriteria Kinerja Keuangan

\begin{tabular}{|c|c|}
\hline Interval & Kriteria \\
\hline $0,50-5,75$ & Sangat Rendah \\
\hline $5,76-11,01$ & Rendah \\
\hline $\mathbf{1 1 , 0 2}-\mathbf{1 6 , 2 7}$ & Sedang \\
\hline $16,28-21,53$ & Tinggi \\
\hline $21,54-26,8$ & Sangat Tinggi \\
\hline
\end{tabular}

Sumber : Data sekunder yang diolah, 2015 


\subsection{Pengaruh Pengungkapan Corporate Social Responsibility Terhadap Kinerja Keuangan Perusahaan Pertambangan yang Terdaftar di Bursa Efek Indonesia 2010-2014.}

Penelitian ini mempunyai tujuan untuk mengetahui apakah pengaruh Corporate Social Responsibility (CSR) terhadap Kinerja Keuangan pada perusahaan pertambangan yang terdaftar di Bursa Efek Indonesia tahun 2010-2014. Variable independen yang digunakan dalam penelitian ini adalah variable Corporate Social Responsibility (CSR). Variable dependen dalam penelitian ini adalah Kinerja Keuangan yang diukur berdasarkan Return On Asset (ROA). Populasi yang digunakan dalam penelitian ini adalah perusahaan pertambangan yang terdaftar di BEI. Penelitian menggunakan periode dari tahun 2010 sampai 2014. Jumlah populasi yang digunakan adalah sebanyak 40 perusahaan. Teknik pengambilan sampel yang digunakan adalah menggunakan kriteria tertentu dimana jumlah amatan yang diperoleh dalam penelitian ini adalah sebanyak 4 perusahaan.

Pengujian yang digunakan dalam penelitian ini adalah uji asumsi klasik (normalitas) dan uji hipotesis (uji $\mathrm{t}$ dan uji determinasi). Hasil uji besarnya adjusted $R^{2}$ berdasarkan hasil analisis dengan menggunakan SPSS 21 diperoleh adjusted $R^{2}$ sebesar 0.382. dengan demikian besarnya pengaruh yang diberikan oleh variabel Coporate Social Responsibility (CSR) adalah sebesar 38,2\%, sedangkan sisanya sebesar 61.8\% dipengaruhi oleh faktor lain yang tidak diteliti dalam penelitian ini.

\section{KESIMPULAN}

Berdasarkan hasil penelitian yang dikemukakan pada bab sebelumnya maka dapat disimpulkan beberapa hal penting dalam penelitian ini yaitu:

1. Pengungkapan Corporate Social Responsibility Perusahaan Pertambangan yang Terdaftar di Bursa Efek Indonesia 2010-2014 sudah lengkap. Implementasi Corporate Social Responsibility (CSR) yang tertinggi sebesar 1,00 atau $100 \%$ pada semua perusahaan sampel ditahun 2010-2014 dengan Implementasi 79 item dari 79 item yang seharusnya dilaporkan dalam Sustainability Report. Sedangkan implementasi Corporate Social Responsinbility (CSR) terendah yaitu 0,20 atau $20 \%$ pada PT. Tambang Batubara Bukit Asam (Persero) Tbk dan PT. Petrosea Tbk ditahun 2014, dikarenakan pengimplementasian pengungkapkan CSR hanya 16 item dari yang seharusnya 79 item yang seharusnya dilaporkan dalam Sustainability Report.

2. Kinerja keuangan pada perusahaan pertambangan yang terdaftar di Bursa Efek Indonesia tahun 20102014 dengan indikator rasio Return On Asset (ROA) tersmasuk dalam kriteria kategori Sedang. Kinerja Keuangan dengan nilai tertinggi yaitu sebesar 26,8\% pada PT. Tambang Batubara Bukit Asam (Persero) Tbk. Sedangkan nilai rata-rata rasio Return On Asset (ROA) terendah adalah 0,5\% pada PT. Petrosea Tbk tahun 2014.

3. Pengungkapan Corporate Social Responsibility (CSR) berpengaruh positif terhadap Kinerja keuangan pada perusahaan pertambangan yang terdaftar di Bursa Efek Indonesia tahun 2010-2014. Besarnya pengaruh yang diberikan oleh variable 1Coporate Social Responsibility (CSR) adalah sebesar 38,2\%, sedangkan sisanya sebesar $61.8 \%$ dipengaruhi oleh faktor lain yang tidak diteliti dalam penelitian ini. 


\section{DAFTAR PUSTAKA}

[1] Anwar, Samsinar, Haerani, S dan Pagalung, G. 2010. Pengaruh Pengungkapan Corporate Social Responsibility terhadap Kinerja Keuangan Perusahaan dan Harga Saham. http://www.pasca.unhas.ac.id/jurnal/files/38fa14eec.pdf.

[2] Azheri, Busyra. 2012. Corporate Social Responsibility: dari voluntary menjadi mandatory. Jakarta: Rajawali Pers.

[3] Bapepam dan LK kep-431/BL/2012 tentang Penyampaian Laporan Tahunan Bagi Emiten atau Perusahaan Publik.

[4] Candrayanthi, Alit A.A dan Saputra, Dharma I D.G. 2013. "Pengaruh Pengungkapan Corporate Social Responsibility Terhadap Kinerja Perusahaan (Studi Empiris Pada Perusahaan Pertambangan di Bursa Efek Indoneia". E-jurnal Akuntansi Universitas Udayana 4.1: 141-158.

[5] Fahmi, Irham. 2011. Analisis Laporan Keuangan. Lampulo: ALFABETA.

[6] Harahap, SofyanSyafri. 2010. Analisis kritis atas laporan keuangan. Jakarta: Rajawali Pers.

[7] Husnan, ahmad. 2013. Pengaruh Corporate Social Responsibility (CSR Disclosure) Terhadap Kinerja Keuangan Perusahaan. Skripsi. Semarang: Fakultas Ekonomi dan Bisnis Universitas Diponegoro.

[8] Indrawan, Danu Chandra. 2011. Pengaruh Corporate Social Responsibility terhadap Kinerja Perusahaan. Tidak Diterbitkan. Skripsi. Semarang: Fakultas Ekonomi Universitas Diponegoro.

[9] Jessica dan Toly, Agus Arianto. 2014. "Pengaruh Pengungkapan Corporate Social Responsibility Terhadap Agresivitas Pajak". Tax \& Accounting Review, Vol.4, No.1.

[10] Karina, Lovink Angel Dwi. 2013. Analisis Faktor-Faktor Yang Mempengaruhi Pengungkapan CSR(Studi Empiris Pada Perusahaan Manufaktur yang Terdaftar di Bursa Efek Indonesia tahun 2011).Skripsi. Semarang: Fakultas Ekonomi dan Bisnis Universitas Diponegoro.

[11] Kasmir. 2013. Analisis Laporan Keuangan. Edisi 1. Cetakan ke-6. Jakarta: Rajawali Pers.

[12] Kristi, Agatha Aprinda. 2012. Faktor-faktor yang Mempengaruhi Pengungkapan Corporate Social Responsibility pada Perusahaan Publik di Indonesia, Jurnal Akuntansi dan Bisnis, Vol. 1, No. 1, Universitas Brawijaya.

[13] Kurnianto, Eko Adhy. 2011. Pengaruh Corporate Social Responsibility Terhadap Kinerja Keuangan. Tidak Diterbitkan. Skripsi. Semarang: Fakultas Ekonomi Universitas Jember.

[14] Kusumadilaga, Rimba.2010. Pengaruh Corporate Social Responsibility terhadap nilai perusahaan dengan profitabilitas sebagai variabel moderating. Semarang: FE-Universitas Diponegoro.

[15] Lageranna, Akmal. 2013. Pelaksanaan Tanggung Jawab Sosial Perusahaan (Corporate Social Responsibility/ CSR) Pada Perusahaan Industri Rokok. Universitas Hasanuddin Makassar.

[16] Maharani, Astrid. 2012. Pengaruh Coporate Social Responsibility Disclosure terhadap Return Saham pada Perusahaan High Profile yang Listed Di Bursa Efek Indonesia (BEI). Tidak Diterbitkan. Skripsi. Jember: Fakultas Ekonomi. Universitas Jember.

[17] Manurung, Dwi Endah Mira. 2012. Analisis Penerapan Corporate Social Responsibility (CSR) pada PT. Perkebunan Nusantara IV-Medan.

[18] Mardikanto. 2014. Corporate Social Responsibility (Tanggung jawab Sosial Perusahaan). Bandung: Alfabeta.

[19] Mernelly, Romi. 2012. Corporate Social Responsibility (CSR): Tinjauan Teori dan Prkatek di Indonesia. Jurnal Aplikasi Bisnis UNRI. Vol. 2 No. 2.

[20] Murti, Wahyu. 2011. Pengaruh Kinerja Keuangan Terhadap Return Saham, Jakarta: Cintya Press.

[21] Octaviana, Natasya Elma. 2014. Pengaruh Agresivitas Pajak Terhadap Corporate Social Responsibility : Untuk Menguji Teori Legistimasi. Universitas Diponegoro Semarang.

[22] Rahayu, Sri. 2010. Pengaruh Kinerja Keuangan Terhadap Nilai Perusahaan Dengan Pengungkapan Corporate Social Responsibility Dan Good Governance Sebagai Variabel Pemoderasi (Studi Empiris Pada Perusahaan Manufaktur di Bursa Efek Jakarta).Skripsi. Semarang: Fakultas Ekonomi Universitas Diponegoro.

[23] Resturiyani, Novi. 2012. Pengaruh Pengungkapan Corporate Social Responsibility Terhadap Kinerja Keuangan: Studi Empiris Pada Perusahaan Pertambangan yang Terdaftar di Bursa Efek Indonesia. Bandung; Skripsi Fakultas Ekonomi Universitas Pasundan. 
[24] Rudito, Bambang dan Melia Famiola. 2013. CSR (Corporate Social Responsibility). Bandung: Rekayasa Sains.

[25] Undang-undang Nomor 40 Tahun 2007 tentang Perseroan Terbatas.

[26] Undang-undang Nomor 25 Tahun 2007 tentang Penanaman Modal.

[27] Utari, Intan Ayu. 2014. Pengaruh Agresivitas Pajak Terhadap Corporate Social Responsibility: Untuk Menguji Teori Legitimasi (Studi Empiris Pada Perusahaan Manufaktur yang Terdaftar di Bursa Efek Indonesia Tahun 2011-2013).Skripsi. Semarang: Fakultas Ekonomi dan Bisnis Universitas Diponegoro.

[28] Wijayanti, Sutaryo Dan Prabowo, 2011. Pengaruh Pengungkapan Corporate Social Responsibility Terhadap Kinerja Keuangan Perusahaan. Simposium Nasional Akuntansi XIV. UNS Banda Aceh 21-22 Juli.

[29] Yoehana, Maretta. 2013. Analisis Pengaruh Corporate Social Responsibility Terhadap Agresivitas Pajak. Universitas Diponegoro Semarang. 